\title{
ECO-INNOVATION
}

\section{ECOLOGICAL AND ECO-INNOVATIVE ACTIVITIES OF THE BANKS}

\section{BOGNA JANIK, KRZYSZTOF KOŁODZIEJCZYK}

Poznan School of Banking, Poland

Jel CLASSIFICATIONS: O16, O31, O32, O44

KEYWORDS: Eco-innovation, ecology, innovation, sustainability, stock exchange

\begin{abstract}
The main objective of our study is to identify and assess some chosen aspects of ecological and eco-innovative activities of the banks listed on the Warsaw Stock Exchange and included in WIG Banks index. The scope of this analysis encompasses selected dimensions illustrating banks' activities in terms of environmental care. These activities also include the identification of eco-innovations being implemented. The analysis of the investigated dilemma was based mainly on the desk research of digital and documentary sources, whereas survey data analysis was used as a supplementary method. The results indicate relatively high differences across environmental care and, in some cases, even lack of any activities. Having that considered, we have identified relatively low eco-innovativeness of the examined banks, mainly product eco-innovations.
\end{abstract}

Source: Janik B., Kołodziejczyk K., 2016. "Ecological and eco-innovative activities of the banks", Perspectives of Innovations, Economics and Business, Vol.16(1), pp.13-20,

http://dx.doi.org/10.15208/pieb.2016.02

\section{Introduction}

Banks as institutions of the financial counseling and mediation services contribute to the allocation of money between economic sectors and, therefore, may support the development of particular sectors as well as contribute to economic growth. The main pillar of their proper functioning is the obedience and implementation of the following basic rules: competitiveness, self-reliance, self-financing, commercialism and universalism. These rules should be followed pursuant to the rule of social justice as the premises of sustainable development.

In accordance with the concept of sustainable development, socially responsible practices of enterprises are realized in at least three dimensions: ecological, social and economic one. Within the scope of this article, the banks' activities will be considered at the ecological level. Bearing in mind their ecological activities, we will make an attempt to distinguish eco-innovative undertakings. It will be a very demanding task to decide which activities conducted by the banks in terms of ecology are innovative and which are treated as an ordinary course of business. Taking into account all the above aspects, the research objective is to identify the facets of the banks in terms of eco-innovations and present some current activities of these banks in the field of environmental action.

The justification to analyze the issue selected is confirmed by previously conducted studies which indicate a relatively low level of innovativeness of Polish enterprises in 
general. It is common knowledge today that the phenomenon of eco-innovativeness is one of the main challenges our economy has to face in the subsequent years. What is crucial here, the issue of eco-innovativeness and other pro-ecological activities conducted by local business entities look similar. Also in this case, the lion's share of the leaders of selected companies cannot exemplify any special achievements in his area. However, it does not mean that all have an identical, indifferent attitude to ecological matters! Although the majority does not do much, there are also those who are trying to initiate changes and introduce solutions which bring environmental benefits. Therefore, it is worth identifying theses good practices of Polish enterprises since the road to a green economy seems to be a foregone conclusion at least in terms of some strategic choices made by the European Union.

An additional argument in favor of conducting research is the fact that it is the financial market which has been undergoing a transformation towards supporting the green economy for some time now. As Dziawgo says, the pro-ecological activity of financial institutions is visible in a few areas, for example: natural resources protection; undertaking supporting initiatives; undertaking relationship activities; implementing ecological aspects in financial transactions (Dziwago, 2014, pp.11-12).

Banks constitute a relatively clean sector of the economy, although they can have a considerable impact on the environment. It results from the use of the resources indispensable to let their offices and departments work including energy and water consumption or waste production. For instance, high energy consumption in banks may be the result of: heating, lighting, electronic equipment, air conditioning and ventilation. The second biggest environmental issue for banks is waste, especially paper. Waste is a natural consequence of their activities, though recently less documentation has been observed including paper correspondence since banks have been using digital media devices, which supports the protection of natural resources because it contributes to generating less amount of paper used and more rational employment. The size of the banking sector as well as applied technologies (banks with their multiple departments or their mobile version) may be extremely crucial for the environment. Many banks realize the importance of ecological information and start to promote their campaign of, for example, saving energy. There may be found qualitative data such as the reduction of electrical energy use by implementing new technologies - LED lighting or the exchange of air conditioning as well as some quantitative data, namely the presentation of solid figures illustrating e.g. the use of electrical energy. In general, banks, apart from their internal activity for the environment, play an important external role strictly connected with financing investments made by enterprises. They support pro-ecological activities of the entities applying for financing or offer saving/investment products relating to the environmental impact. In terms of their external activities there can be distinguished two groups of banks. The first group includes these banks whose ecological activity is provided in strategic documents and it suits their core activity, whereas the second group encompasses such banks, which so far have only built the image of eco-friendly banks. The first group offers a wide selection of products and pro-ecological services as well as uses the tools of environmental risk management. The second group concentrates on offering selective products and services as well as is active in the area of pro-ecological marketing.

\section{Eco-innovation - the diversity of meanings and approaches}

In order to 'lay the foundations' to realize a selected research approach, the first step involved the review and analysis of the term eco-innovation as such. The perception and definition of eco-innovation has been changing throughout almost 20 years. The first definition was proposed by Fussler and James (1996) who defined ecoinnovations as „new products and processes which provide customer and business - 14 - 
value but significantly decrease environmental policy". After some time the definitions became more complex and referred to the concept of eco-innovation more precisely. Among many definitions which were created throughout 20 years, we have chosen for the purposes of this article these which were created by huge research teams. They have become the basis for the Environmental Technology Action Plan (ETAP, 2006), which was adopted by the European Commission and was supposed to support achieving the goals set by the Lisbon Strategy; Oslo Manual and other later studies published by the Organization for Economic Cooperation and Development (OECD, 2005); the report summarizing the Measuring Eco Innovation (MEI, 2007) project coordinated by Rene Kemp and Peter Pearson ${ }^{1}$. The choice of proposed definitions results from the fact that they define eco-innovation activity in a broader sense and do not refer only to technological aspects.

Pursuant to the definition included in the ETAP, eco-innovation is "the production, assimilation or exploitation of a novelty in products, production processes, services or in management and business methods, which aims, throughout its life circle, to prevent or reduce environmental risk, pollution and offer negative impacts of resource use (including energy)". The ETAP is a document which presents a specific roadmap to promote pro-ecological technologies bringing entrepreneurs and scientists closer to work on common projects.

According to the OSLO Manual, eco-innovation "is the implementation of a new or significantly improved product (good or service), or process, a new marketing method, or a new organizational method in business practice". It is not a classical definition of eco-innovation since the authors define widely understood innovations, however, later on the definition was adjusted strictly to the ecological context. „Eco innovation can be generally defined as innovation that result in the reduction of environmental impact, no matter whether or not that effect is intended. Various ecoinnovation activities can be analysed along three dimensions:

- Target (the focus areas of eco-innovations: products, processes, marketing methods, organizations and institutions)

- Mechanisms (the way in which changes are made in the targets: modification, redesign, alternatives and creation)

- Impacts (effects of eco-innovation on the environment)".

According to the $\mathrm{MEI}$ report, "Eco-innovation is the production, assimilation or exploitation of a product, production process, service or management or business method that is novel to the organization (developing or adopting it) and which results, throughout its life cycle, in a reduction of environmental risk, pollution and other negative impacts of resources use (including energy use) compared to relevant alternatives".

The above presented definitions seem to draw a picture of eco-innovation as a new concept of huge importance both for the development of an enterprise as well as for the creation of a suitable environmental policy, and it is unique itself. Eco-innovation should be innovative, unique, create new values in the man-environment relation and be applicable. The effect of introducing eco-innovation are the benefits for the environment (see Figure 1).

The quoted definitions emphasize four areas which may be influenced by the innovation process in terms of environmental protection, namely product, process, organization and marketing (PPOM). In the application of the first two, some changes are required of technological nature, whereas in the remaining two, of non-

${ }^{1}$ The idea of eco-innovation was also discussed by Klemmer (1999); Driessen and Hillebrand (2002); Huppes et al. (2008) in ECODRIVE Report; Oltra and Saint Jean (2009); Reid et al. (2008).

-15 - 
technological character. A crucial element mentioned in the above definitions is the applicability of eco-innovation. It means that eco-innovation may or even should be financed within scientific research, but only when it will have a value for the recipients.

FIGURE 1. THE MAIN GOAL OF ECO-INNOVATION

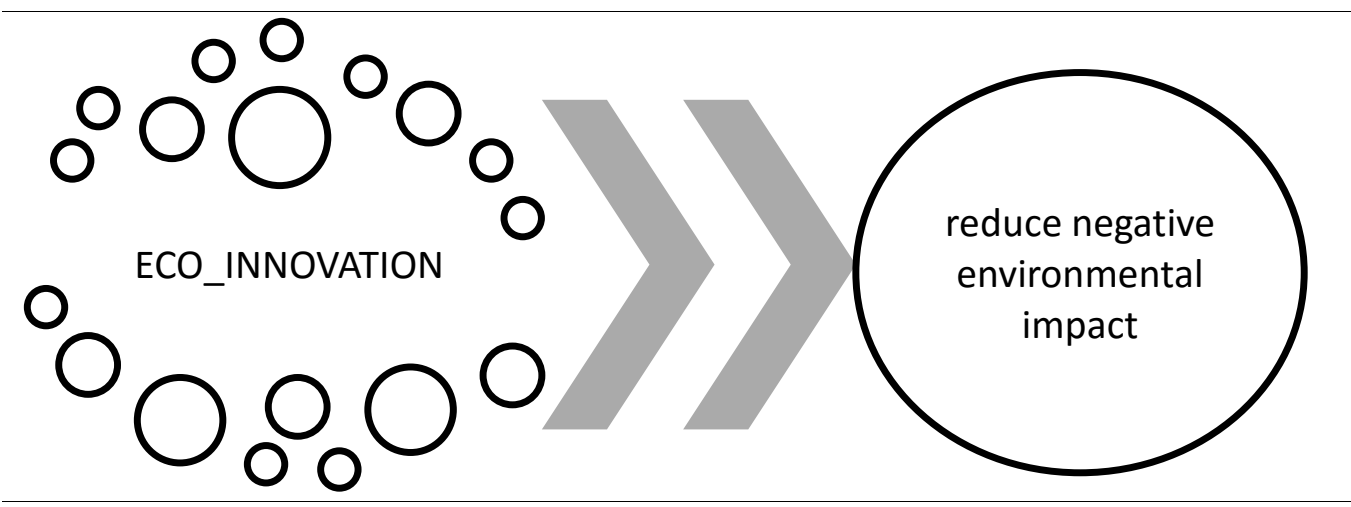

Source: the authors' own analysis.

The above mentioned applicability may have a few premises.

- economic: cost reduction/saving, increase of sale and production.

- directive: international agreements, directives, legal regulations at the domestic level.

- non-directive: a free selection done by social actors as a result of their conviction.

Also, numerous official documents of many countries (government policy) define ecoinnovations for the purpose of realized strategies. In Denmark, for example, the definition was precisely quoted from the Environmental Technology Action Plan (ETAP), in France eco-innovations were divided into two groups, i.e. innovation in environmental technologies and innovation in eco-responsibility of economic and social actors. An interesting definition seems to be the one in the Japanese legislation because it emphasizes the purpose of eco-innovation, „....for funding a sustainable economic society by reforming technical innovation and creating a social system that ensures minimum impact on the environment". In the United States, the equivalence of such terms as environmental innovation, clean technology and sustainable manufacturing is strengthened.

Summarizing, eco-innovations may be of both technological and non-technological nature, nonetheless, the type of introduced eco-innovations is adjusted to the economy sector (production, service). The study presented below analyzes the banking sector, hence technological eco-innovations will play a much greater role.

\section{Methodology}

While preparing our research, we decided to concentrate on the banks listed on the Warsaw Stock Exchange in WIG Banks Index. In order to select a homogenous 
research sample, 12 banks were selected out of $15^{1}$. The remaining three banks are foreign banks which have much bigger experience in environmental activities and, thus, have much higher standards. Some of the analyzed banks (five) are also listed in RESPECT index (Sustainability Index).

The analysis has involved the following set of activities within the scope of environmental issues.

1. Environmental reporting and certification.

2. Environmental care in practice: reporting policy, objectives, data, products/services.

In order to achieve previously indicated purpose of the study, we have come up with a set of research methods, which include literature overview, survey method and the analysis of internet websites content as well as comparative analysis. The first of the mentioned methods was meant to be a selection tool for a proper research approach and determining its theoretical basis. The survey questionnaire was aimed at collecting primary data concerning innovative activities of selected companies, including eco-innovative ones. It is worth mentioning that the prepared set of questions was made, which also considered the peculiarity of analyzed entities, namely the sector of financial services. Finally, thanks to the content analysis of internet websites, we also wanted to check and assess the message particular companies convey while referring to environmental activities, in particular a type of published information according to the criteria specified for the purpose of the research. Hence, we decided to take advantage of the research method used by $\mathrm{M}$. Jeucken (2004).

In the preparation stage, we noticed that the methodology assumed by Jeucken could not be fully applied. We decided to adapt it to our needs. First of all, the original approach by Jeucken did not refer only to the environmental dimension of the financial sector. It encompassed a much wider range, namely socially responsible practices. Secondly, we decided to adjust the criteria defined by Jeucken and the weighted mean of particular activities to the Polish conditions, including the current phase of development of pro-ecological activities at the level of domestic companies.

As a result of adjusting a selected research approach, we defined four main groups of criteria on the basis of which we prepared sub-rankings in the next stage as well as the main ranking of the analyzed banks (see Table 1$)^{2}$. As it is clearly noticeable, the greatest attention was put to the criterion „generic published information" (40\%), which consisted mainly of quantitative and qualitative data referring to internal and external activities as well as the goals of the companies in terms of "environmental care". A smaller attention (30\%) was given to green products available on the market, however, we limited ourselves only to: time deposits, investment funds, loans and credits, leasing and "other products". The third considered criterion was "communication" (20\%). This highly demanding criterion was based on three components: environmental policy, environmental reports and ISO 14001 standards or EMSs. The last criterion was "social issues and charity" (10\%), which consisted of the support for educational and scientific activities, activities conducted by higher education institutions, and activities for local societies as well as the level of employees' involvement in environmental projects.

The realization of the research study revealed challenges we had to deal with. The context we assumed, namely a monolithic research sample, provided the possibility of adopting clear criteria of assessment. On the other hand, a limited geographical area

\footnotetext{
${ }^{1}$ We relied on data from the end of March 2015.

${ }^{2}$ The share of separate group in this research was slightly modified then Jeucken (2004) approach because author examines not only environmental care but value based activity.
} 
(Polish banks) does not allow for making the scale bigger. Another limitation we encountered was a very poor survey return sent to the banks for research purposes. Despite repeated requests, including telephone calls, only one bank sent back a completed questionnaire. Hence, the range of used analytical tools was seriously limited, which consequently was reflected in smaller than expected results of the project. Moreover, the disorder and/or non-systematization of websites content turned out to be another obstacle in the realization of research tests, especially in terms of social responsibility, including the reference to natural environment.

\section{Results}

The discussion concerning the results of the realized research will be conducted according to the criteria classification presented in Table 1. As far as generic published information is concerned, a strong contrast was visible between banks listed in Respect Index and others. The former occupied the first four positions in the ranking (after adding the points given in each detailed criterion). They obtained more than $50 \%$ of the maximum points. On the other hand, the results of the latter group attract the attention as well, namely three banks which obtained zero points. The analysis also shows the third characteristic group of the banks which, though, collected some points, still it was achieved only in a few detailed criteria.

The most demanding challenge for the analyzed banks was the communication of environmental activities („communication”). Here, a peculiar dualism is visible among the banks. There are the leaders who in a more or less formalized way work on their socially responsible image, including their involvement in natural environment issues. There are also such banks which do not show any proper interest in the issue of social responsibility including ecology. As far as the leaders are concerned, at the moment of our project realization, only two banks listed in WIG Banks (both in Respect index) obtained a prestigious certificate - ISO 14001, which confirms the implementation of a formalized system of environmental management in a company. The remaining banks, though active in terms of a given criterion, were proud mainly of their environmental reporting, most of all within the reports of social responsibility. Only one bank communicated its own pro-ecological activities on the basis of the environmental report, emphasizing the importance of environmental issues in its own business activity. It is also worth emphasizing that a vast number of banks (four banks including three in Respect index) informed about their own environmental policy, publishing at least the extracts of proper documents on company websites.

In terms of pro-ecological support for social issues and charity, a vast majority of the banks showed a pretty large activity. Only three banks did not report any activity in communication using Internet information about company.

The last but not least main criterion was the offer of green products proposed by the banks. We came up with five detailed criteria (see Table 1). The actual offer did not appear to be impressive. We can talk about a relatively rich offer of the researched sample of banks (seven banks) only when it comes to green investment funds. However, it should be emphasized that the main contribution was made by investment funds since banks only distribute their offer. Relatively numerous banks offered also loans and credits aimed at supporting pro-ecological activities (five banks). As far as the other products are concerned, we reported one bank offering a pro-ecological deposit and one offering pro-ecological leasing.

Table 2 presents the ranking of the banks based on previously specified criteria. This comparison clearly indicates an important differentiation of approaches to environmental issues. Out of the examined group, we selected three groups: Active Banks (AcB) - five banks (MILLENNIUM, BOS Bank, BPH Bank, HANDLOWY, ING BS); Preventive Banks (PrB) - three banks (BZWBK, mBANK, PKO BP); Passive Banks (PaB) four banks ALIOR, GETIN HOLDING, GETIN NOBLE BANK, PEKAO). The first group (IG) 
consequently accepts the challenges of green economy. The activities performed by these banks are not one-action-like, but rather are characterized by regularity and growing level of formality. The second group (IIG) consists of the banks which probably notice the importance of this area, which is proved by some attempts to start pro-ecological activities, but they are usually at their starting point in contrast to more decisive undertakings. The estimates, however, look poorly for the third group of banks (IIIG). These banks make an impression of complete indifference towards environmental issues.

TABLE 1. "ENVIRONMENTAL CARE (EC)" OF THE COMPANIES LISTED IN WIG BANKS INDEX - MAIN AND DETAILED CRITERIA

\begin{tabular}{|c|c|c|c|c|c|c|}
\hline \multirow{3}{*}{$\begin{array}{l}\text { Detailed } \\
\text { criteria with } \\
\text { weighted } \\
\text { means }\end{array}$} & \multicolumn{6}{|c|}{ MAIN CRITERIA WITH WEIGHTED MEANS } \\
\hline & $\begin{array}{l}\text { Generic published } \\
\text { information }\end{array}$ & & Products & & Communication & Social issues and charity \\
\hline & $40 \%$ & & $30 \%$ & & $20 \%$ & $10 \%$ \\
\hline 1 & $\begin{array}{l}\text { Quantitative data } \\
\text { about Internal EC }\end{array}$ & $4 p$ & $\begin{array}{l}\text { Time deposits } \\
\text { (investment/structured) } \\
\text { with the allocation of a } \\
\text { part of or all the } \\
\text { resources in pro- } \\
\text { ecological solutions. }\end{array}$ & $3 p$ & $\begin{array}{l}\text { Environmental } \\
\text { policy }\end{array}$ & $\begin{array}{l}\text { Support for } \\
\text { educational, } \\
\text { scientific and higher } \\
\text { education institution } \\
\text { activities }\end{array}$ \\
\hline 2 & $\begin{array}{l}\text { Qualitative data } \\
\text { about Internal EC }\end{array}$ & $1 p$ & $\begin{array}{l}\text { Investment funds } \\
\text { (shares distribution of } \\
\text { pro-ecological funds) }\end{array}$ & $3 p$ & $\begin{array}{l}\text { Environmental } \\
\text { Reporting }\end{array}$ & $\begin{array}{l}\text { Activities for local } \\
\text { communities }\end{array}$ \\
\hline 3 & $\begin{array}{l}\text { Objectives for } \\
\text { Internal EC for the } \\
\text { Future }\end{array}$ & $3 p$ & $\begin{array}{l}\text { Loans/credits for the } \\
\text { undertakings } \\
\text { contributing to the } \\
\text { limitation of } \\
\text { enterprises/institutions' } \\
\text { influence and } \\
\text { individuals } \\
\text { (microloans/credits) on } \\
\text { the pollution of water, } \\
\text { air and soil. }\end{array}$ & & $\begin{array}{l}\text { ISO } 14001 \text { or } \\
\text { EMSs }\end{array}$ & \\
\hline 4 & $\begin{array}{l}\text { Quantitative data } \\
\text { about External EC }\end{array}$ & $2-4 p$ & Leasing (as above) & $3 p$ & & \\
\hline 5 & $\begin{array}{l}\text { Qualitative data } \\
\text { about External EC }\end{array}$ & $1 p$ & Other products/services & $3 p$ & & \\
\hline 6 & $\begin{array}{l}\text { Objectives for } \\
\text { External EC for the } \\
\text { Future }\end{array}$ & $3 p$ & & & & \\
\hline
\end{tabular}

Source: The author's own analysis on the basis of Jeucken (2004).

Among the reported pro-ecological activities of the banks, there dominate these which do not fulfill eco-innovation criteria. The banks going into the direction of green economy are not innovators but rather implement pro-ecological standards beneficial to the natural environment. Eco-innovative dimension of bank activities can be discussed only in terms of products. However, in this case, apart from one bank, the range of activities is very narrow. The research indicates that green products offered by the banks are still more an exception rather than a rule in the offer available on the market.

\section{Conclusion}

The conducted research proved that pro-ecological activities of selected Polish banks showed a wide variety. Still, the division of the banks into three groups seems to be 
prevailing and observable. The first group, so called Active Banks (AcB) consists of, with one exception, these banks which are listed not only in WIG Banks Index but also in RESPECT Index. It concentrates the companies of various businesses which not only declare but also conduct their socially responsible activities including the environmental dimension. The second group of banks, so called Preventive Banks $(\mathrm{PrB})$, undertakes pro-ecological activities, still they are of rather non-formalized character and refer mainly to selected areas of activities. It can be concluded that these banks are just at the beginning of the process of changes as far as environmental care is concerned. The last group consists of Passive Banks (PaB) which show very limited or even lack of ecological activities. As many as three of them, at least on the bases of the information included on their websites, did not do anything in the discussed area.

Pro-ecological activities conducted by the banks include also eco-innovations. Our research showed, however, that even the leaders played a marginal role in environmental care - except from one bank - they did not show any signs of ecoinnovativeness. Individual eco-innovations were detected only in one selected criterion, namely bank products and services.

In our opinion, further research on the involvement of the Polish banks in environmental issues should be continued in a systematic way. The necessity to broaden the research on bigger and wider selection of banks is obvious, especially those functioning in Central Eastern Europe as well as in other EU members.

\section{References}

Driessen P., Hillebrand B., 2002. "Adoption and diffusion of green innovations", In: Nelissen W., Bartels G. (Eds.), Marketing for sustainability: Towards transactional policy-making. IOS Press Inc., Amsterdam

Dziawgo L., 2014. "Greening financial market", Copernican Journals of Finance \& Accounting, Vol. 3(No.2), pp.9-24. http://dx.doi.org/10.12775/CJFA.2014.014

ETAP, 2006. Environmental Technology Action Plan. Available in: http://ec.europa.eu/ environment/ecoap/pdfs/etap_action_plan.pdf

Fussler C., James P., 1996. Driving eco-innovation: a breakthrough discipline for innovation and sustainability. Pitman PUB, London/Washington, DC

Jeucken M., 2004. Sustainability in Finance. Banking on the Planet, Eburon Publishers, Delft

Huppes G. et al., 2008. Measuring Eco-Innovation: Framework and typology od indicators based on causal chains. Final report of the ECODRIVE project

Kemp R., Pearson P., 2007. MEI project about Measuring Eco-Innovation, Final report. Maastricht

Klemmer P., 1999. Innovation and Environment. Berlin: Analytica-Verag

OECD/Eurostat, 2005. Oslo Manual: Guidelines for Collecting and Interpreting Innovation Data, 3rd Edition. The Measurement of Scientific and Technological Activities. Paris: OECD Publishing. http://dx.doi.org/10.1787/9789264013100-en

Oltra V., Saint Jean M., 2009. "Sectoral systems of environmental innovations: An application to the French automotive industry", Technol Forecast Soc, Vol.76, pp.567-583, http://dx.doi.org/10.1016/j.techfore.2008.03.025

Reid A., Miedzinski M., 2008. Eco-innovation: Final Report for Sectoral Innovation Watch, Technopolis Group, Brighton 